\title{
İsviçre hukukuna göre mülkiyetin nakli ${ }^{(*)}$
}

\author{
Yazan: \\ Andreas $r$ TLHP
}

Tercüme eden:

Kudret AYITER

Ankara Fuluk Fakilites:

Medeni Funuk Asistant

I.

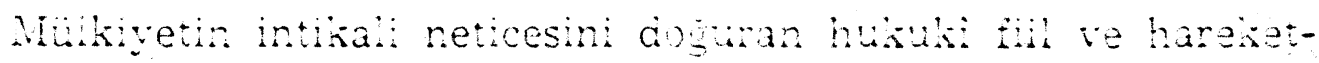

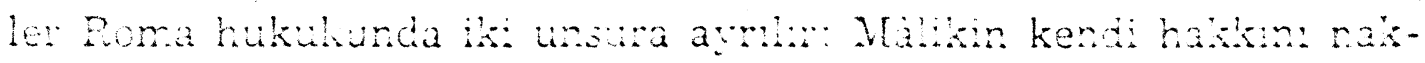

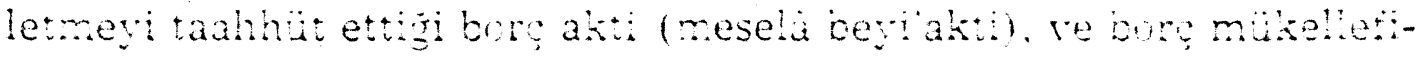

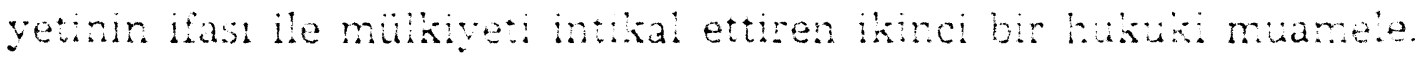

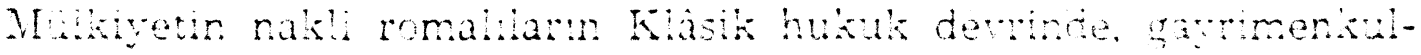

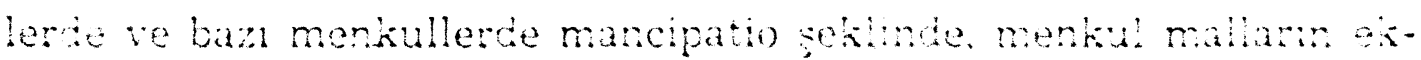

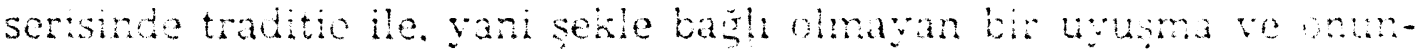

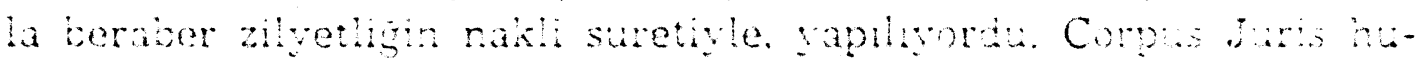

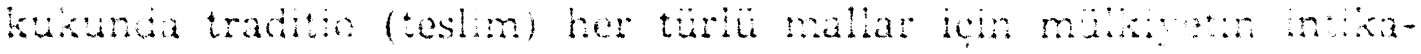

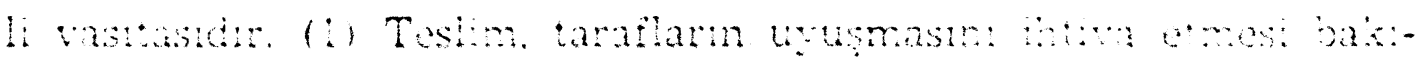

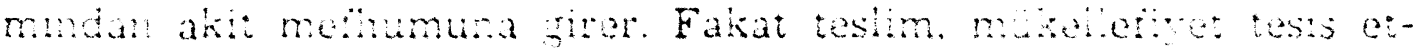

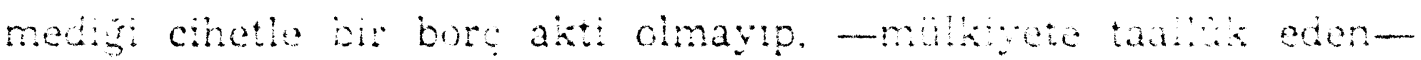

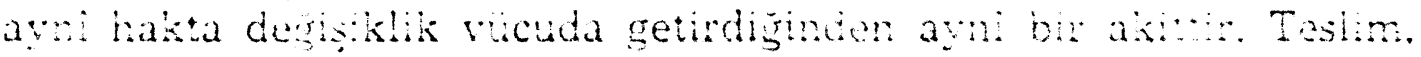

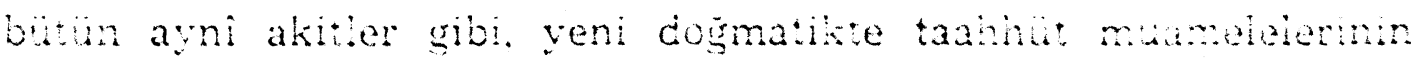
(Verpflchtungeschäfte) zidd olarak tasamuf (Vertans) (a) daniten hukuki muameleler sintfma cahidir.

Pandekt Fukukurda tesim le tesimn dayndy boy asta - tri buna teslinin illet: (causa tmaditonis) deriz- ansindaki mu-

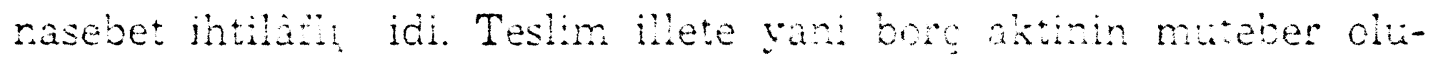
Sura baglmidu. Yoksa lleti bulunmasa da -mäceret darak- hükim irade eder mi? Eski ilmi içthatiarda tesimin micerret oldu-

(*) Eigentumsübertragung nach schweizerischem Rechte. Zeitschrift fü: Schweizeriches Recht dergisi yeni tertip kinknc1 cilt. Easel 192:. S. 40-74

(1) Eski kazaî içtihatlarda traditioya mülkigeti iktisabin modus'ij (tarzi, ciheti) ve borc aktine titulus'u (sifatı, senedi) denirdi.

(2) Der Allgemeine Teil des Deutschen Bürgerlichen Recht adi ese-:min $§ 5+$ ile karşllașt:r. 
ğu kabul eäilmiyorảu. 19 uncu asirda teslimin mücerret oluşu -itirazsiz kalmamakla beraber - (3) kabul edilmiștir. (4) Bilhassa, bir taahhüdün ifası zimnmcia yaplan teslimde taahhüt mevcut oìmasa da mülkicyetin intikal edeceği -gibi tatbikatta şüphesiz mühim olan bir duilum için-kabul edildiğ görülüror. Bir sseyi teslim eden kimse, o şeyin istirdadin talep edemez (vindicatio); ancak borçlu olmadiğ: halde borçlu imiş giti teslim ettiğ şẹi borçlar hukukuna davanan sebepsiz iktisap mütaebesi lle geri istivebilir (condictio indebiti). Zira tesellüm ecen, mülkyeti iktisab etmis ve bu suretle sebersiz iktisapta bulummuștur.

Teslimin mücerret telakki edilis ik baksta insana hukuk it-

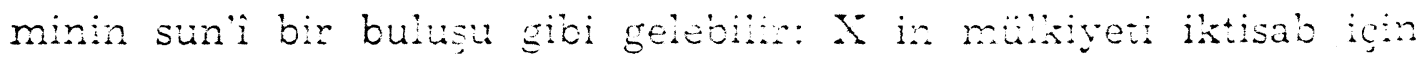
hakh bir sebebl olmadig haice kanth kendisine niçin muktet hakkn tanmakta re akabinde sebersiz mal intab mittalebest gbi doiambach bir yolla bu haks gon amaktacu? Fuma hukuku-

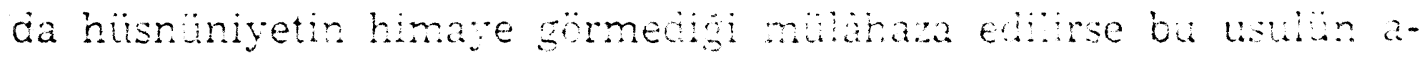

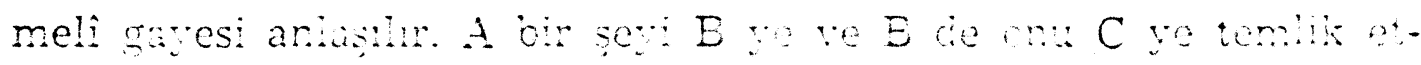

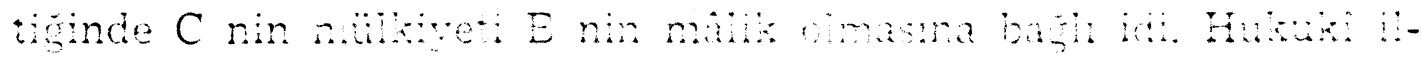

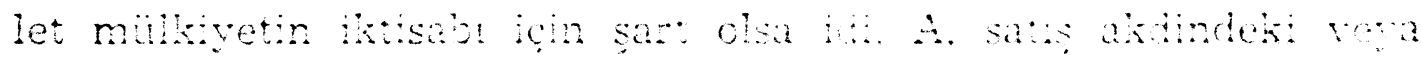

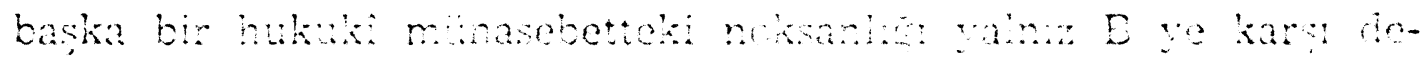

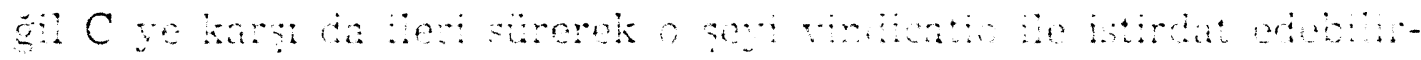

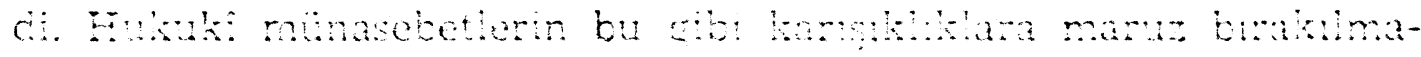

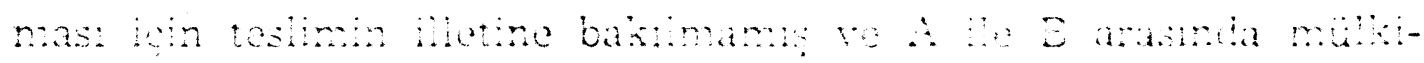

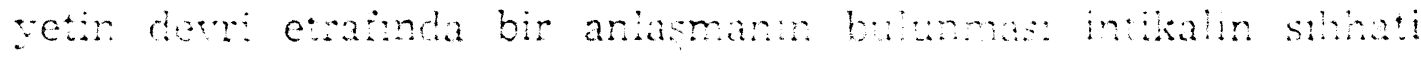

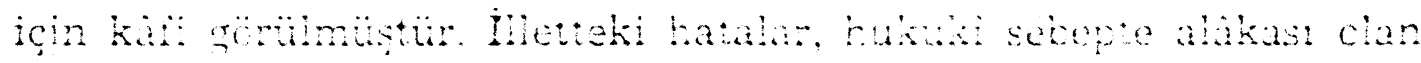

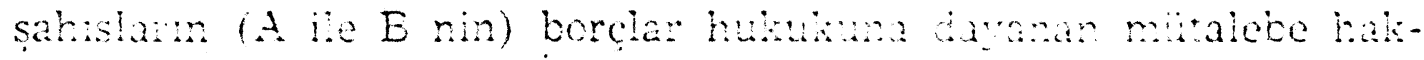

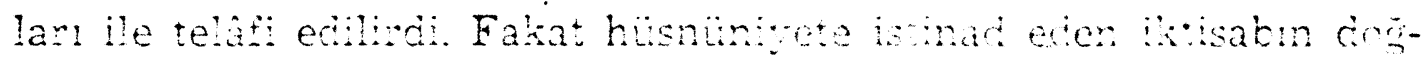
mas. teslimin mïcerret vasm alls vers havatum bir zaruret cl-

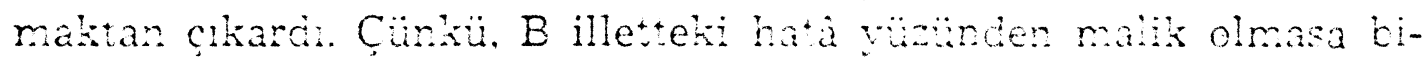
le. E rin iktisab iletindeki bu hatay bimever C harunget sobebiyle malik clur. Buna ragmen müceret toslim. hisninivetin hi-

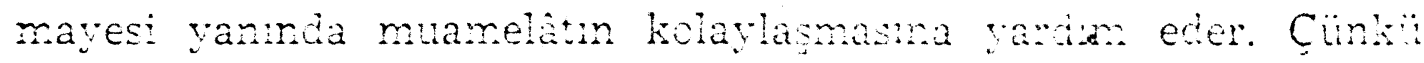
bu sayere C. selefi B rin iktisaptaki ingtrle higon vechile messil olmyacağ gib: iktisab sebebindeki bin haticar colay da bir caraya karımak re cnu gümek durumuna dismivecektr.

Modern Hukuk sistemleri muhtelif telàmil vollari tutmuşarc.r. Fransiz hukuku mülkivetin iktsabm mümkin olduğu kadar

(3) Bihassa Stroha!. Jahrb. f, Dogm. 27, 340 karșiastir.

(4) Windscheid § 172 rct $16 a$, Dernburg, Pand. 1 \& 213 not 7 . 
corç akti ile birleștirmiștir. Fransiz Medenî Kanuru 1138. Müșteri satıs aktinin tamamlanması ile malik olmakta ve main teslimi cnu, ilàveten, ancak zilyet kilmaktadr. Yalnı nev'i ile muayyen bir seyin satılmasinda mülkivet o sey verilmeden evvel iktisab edilemez. (5). Gayrmenkullerde sart clan tapu cisiline kaylt dahi müsieriye Esasen sahibi cldugu mülkiveti temin etmeyip. billakis yalnz ücürcü şahılara karşı hukuki durumunu kuvvetlendirir. Mülkyetin iktisabı satis altine istinad ettiginden, satıs aktinin muteber olnaması halinde milkiretin intikal etmemis oldugu manuken kabul edilmelidir. Satzonm burada kenuiz undesinde buinar. mulkyeti dermevan edeonmes lazmdir. Mishyattan olan mallana at borclar müstesna, sebepsiz mal iktisabma davanan mutalebsye burada yer yoktur. Buna ragmen Fransa Medeni kanunu 13 g6 ve

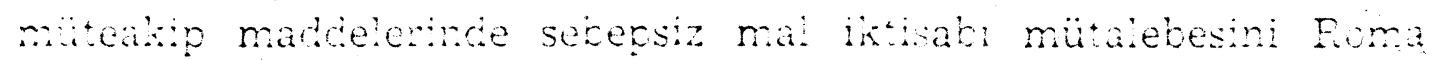

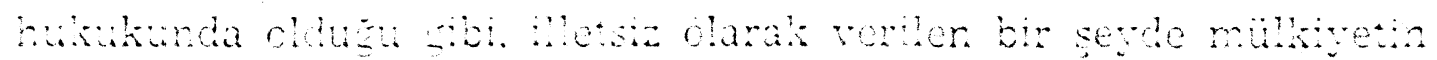

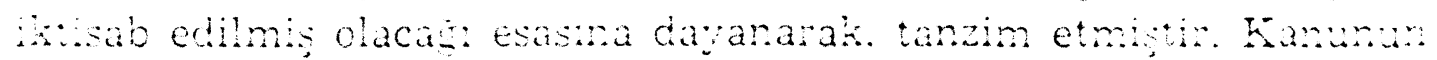

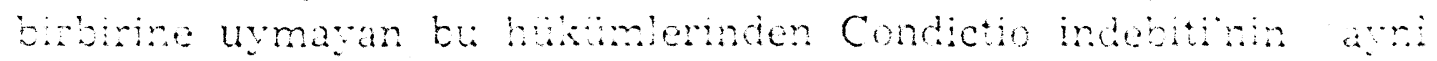

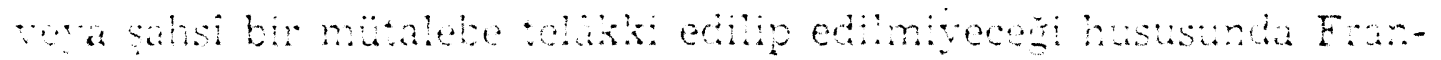

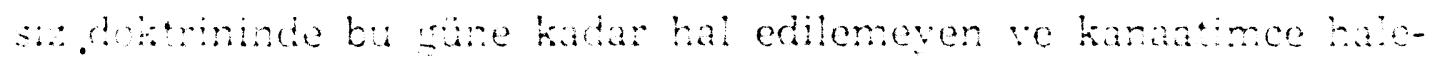

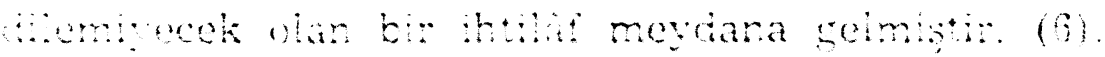

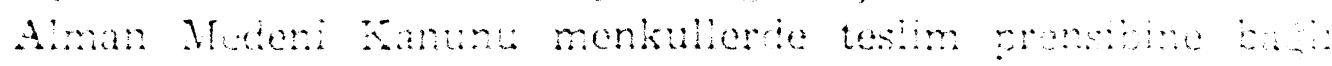

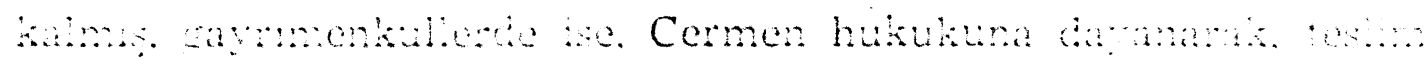

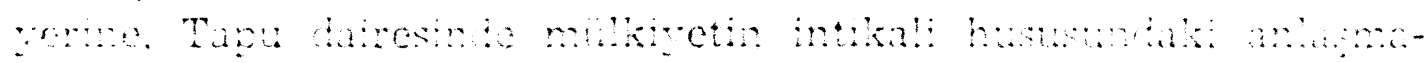

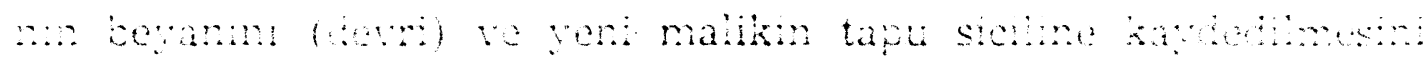

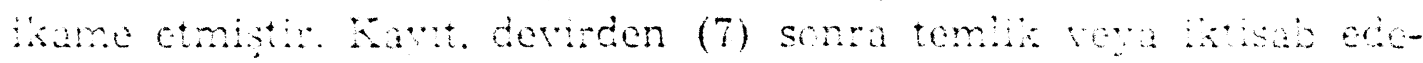

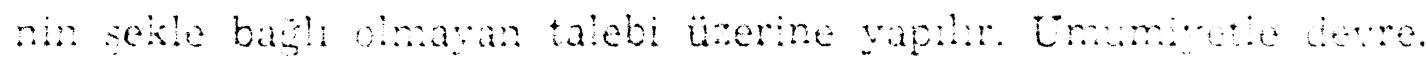

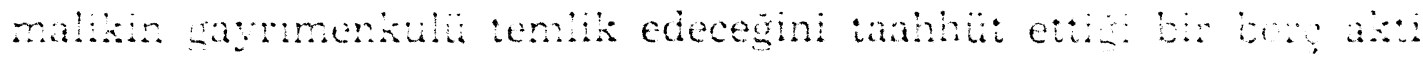

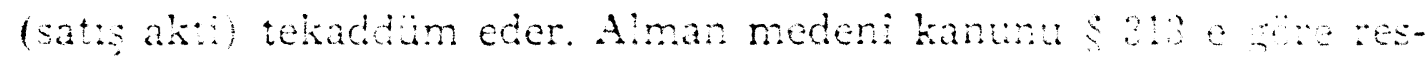
mi seklce yaplmast hab eden bu akt makyein maka lyts sart

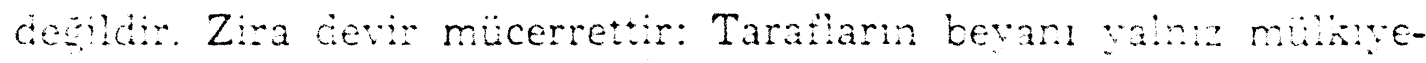
tin intkaline at clup bu intikalin llletine (causa) tailik etmez:

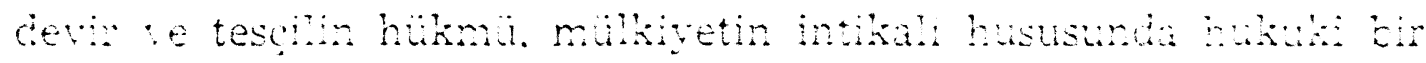

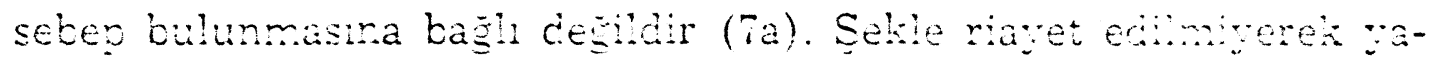

(5) Fransiz Fukuku valniz bu haide ayri bir aisid tanmaktadr.

(6) Crome. Begriff der causa. Zeitschr. f. franz. Ziviir. 21, 304: Zachariä-Crome $\S 296$ zu Note 10; Aubry et Rau $\S 441$ Bote 37; Fuc Commentaire cu C C VIII Nr. 4C0; Planiol, Traité élémentaire du C C II Nr. 892.

(7) Alman Tapu sicil nizamnamesi (Grunbuchordnung) \& 20.

(7a) Mücerret ayni akit hakkinda sert bir tenkit bu kerre Rumpf. Arch. f. Zivil. Praxis 117,361 ve müteakiptecir. 
pilan ve bu sebeple hükum ifade etmeyen bir satiș akti devir ve tesçil ile hüküm ifade eden bir hale gelir. Alman Medeni Kanunu § 313 cümle 2. Bazı devletler (bihassa Bavyera. Würtemberg ve Baden) Tapu sicil nizamnamesinin 93 inci maddesinde mahalii kanurlar lehine taninan kaydi intiraziye dayanarak bu umumi kaidelerden zahiren avrılmişlardir: Buna göre devir valnz resmi şekilàe yapilmiş bir borç mukavelesi ibraz edildigi takdirde kabul edilebilir. Bu usule notere gitme mecbudiveti denir. Ancak bu hüküm yainiz usule tealluk etmekte ve nazar itiba:a alnmámasi tesçilir. Aiman Devletinin rukukuna göre muteber olusuna tesir ememeltedir. (3).

\section{II.}

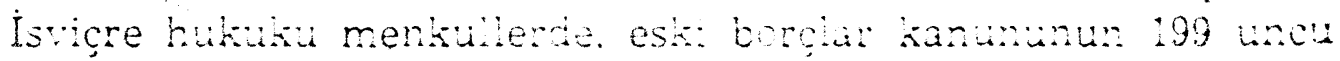
madcesinde kabu: edimiş olan teshm prensbiri muhataza ermi.

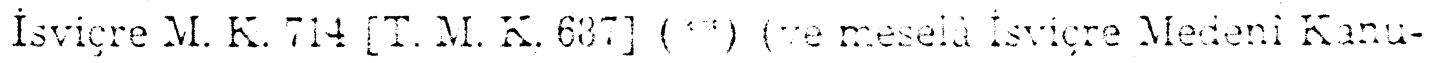

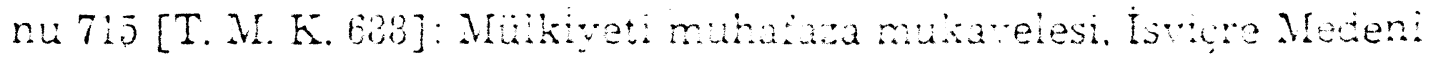

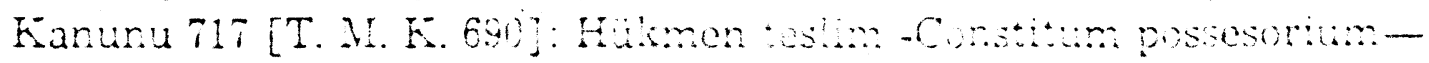

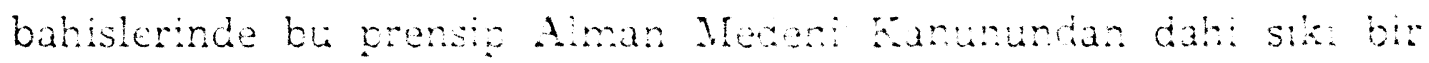

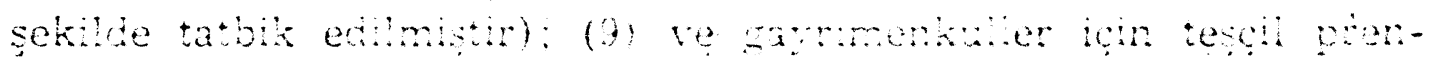

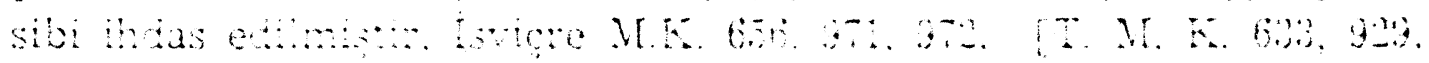

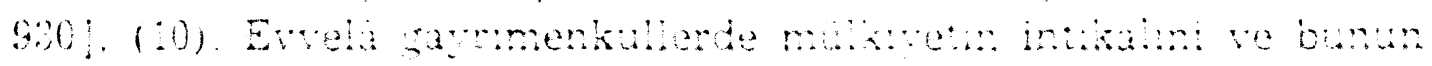

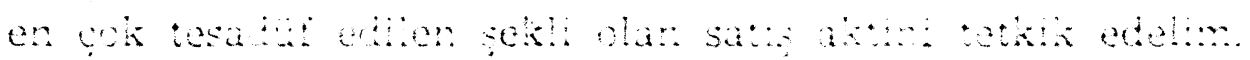

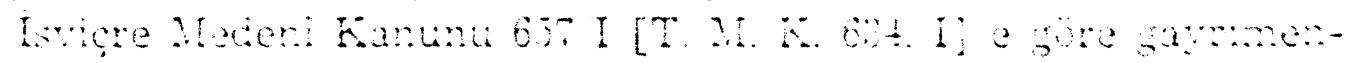

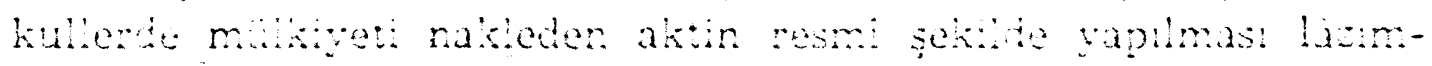

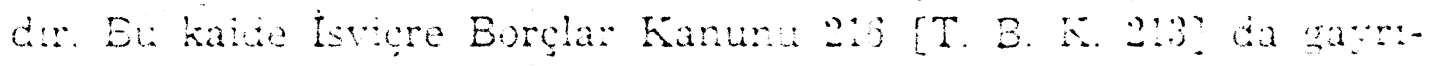

(3) Staudinger. Aman Medeni Kmunu 925 hakindiki B I iadSat:

(") Mitercim notu: Isviçre M. K. madesine tekabul eden T. M. K. maddeleri [ 1 içinde gösterimiştir.

(9) Isvigre Medeni Kanunu 717 nei maddesindex miku! hükmü lie, A:man hukukunda hüsninivet sahibi alacaklian tahammil edimez sekilde majdur ecen, mefhumlar arasındaki incellkler dolaysiyle kullanıssiz hale geten

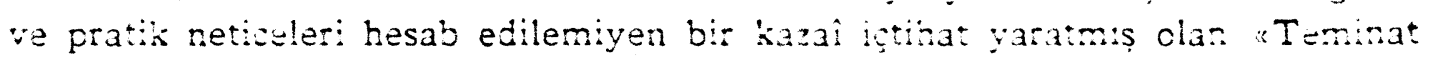
için mülkiyetin nakit, ndeki suistimallerin ondne gemiștis. Benim Aljem. Teil § 77 III ü karșilastr.

(10) Tesçil prensibi Isviçre Borçlar Kanunu 242 II [T. B. K. 237. II de: Gayrimenkullerde hibe. tapu siciline kaydedilmekle tamam oiur" cümlesi ile tekrar edilmistir. Bu cümle hem lüzumsuzdur hem pek doğru değildir. Çünkì bir kimsenin bir gayrmenkulü ivazsız olarak nakledeceğ: taanhüdu içinde hibe mündemiçtir. Yalnız, Isviçre M. K. 656 [T. M. K. 633] da zikredildiğ! g: ‘: hibe edilmiṣ gayrmenkulïn mülkiyeti tesçil iie intikal etmiṣ olur. 
menkullerin beyi' aktinde, ve İsviçre B. K. 243 II [T. B. K. 233. II] de bir gayrimenkulü merzu ittihaz etmiş olan hibe vaatlerinde tekrar edilmiștir. SSekle riayet müekelleriyei yamz mülkiyetin nakli vaadinde değil, bütün akte ve hasren satıs aktinde semenin miktarına da şamildir. (10a). Bundan dolayı senette, hakikatte kararlaştırıldığindan daha dun bir semen gösterilmișse akit batıldır. Aksi halde de (seredin hakikatte kararlaștirlmis olandan daha yüksek bir satıs bedelini intiva etmesi takdirirde de) mukavelenin batil oldigunu kabul etmek daha dogru olur. (10b).

Malikin, gayrmenkulürü temlik edeceğni taahhüt (11) ettigy borc akti, garmenkul mükivetini iktisap etmenir dayndigh hukuki illettir. Isuçe M. K. 665 I. [T. M. K. 6!2. I]. Bu illet, gerek seki bakmdun (Tapl dairesince takip ednecek usul itibarivle), gerekse maddi bakmdan - vani muteber bir tesclin santi clarakehemmiyetidir

Tesçilin sekli sartia: șinlarda:

1 - Tasarufun tanlik ettigi gayrmenkulur malks tamatndan vaznl bir beyan. Isvẹte M. K. 96\%) I. [T. M. F gy I]. Bu beYan 2.2 Subat 1910 tarhli nizamnamentn 11 ve muteake madele-

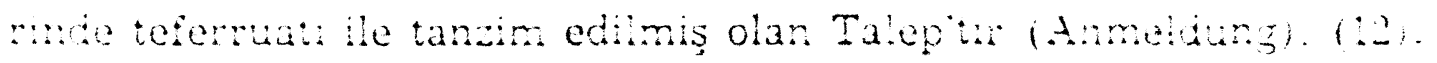

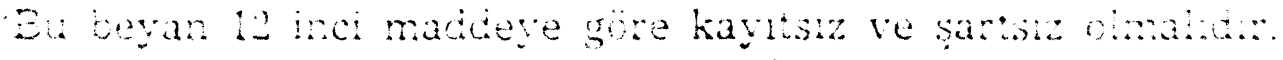

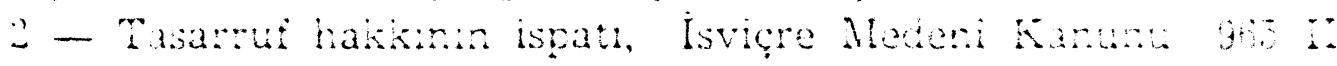

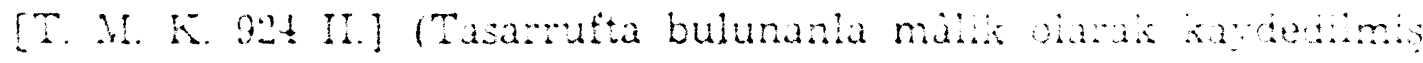

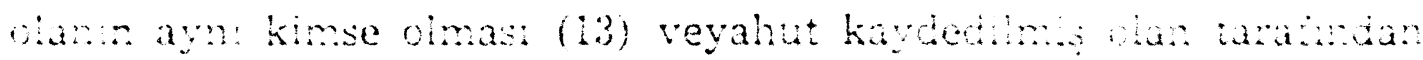

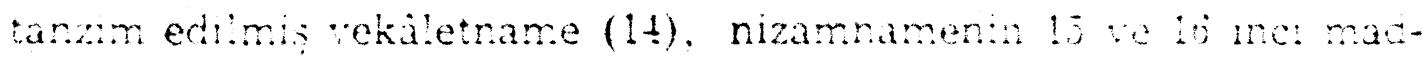
dolers). (15)

(10 a) Weiand 65: ye at: 7 not, Leemann, 657 ye at 15 ine not. Aman Temyz Makkemesinin 93 S. 219 hukmüi mukayese et.

(106) Alman Temyiz Mahkemesi: 98 S. 115 bu fikirdedir. Senede der edikis yuksek miktarlara hakikatte mevzubahis clan daha wiak miktar dahil vidugundun bu karardaki görüs şüphe ile karșlanabir.

(:) Aṣağdaik not 24 ü karșllaṣtir.

(12) Bu tabir Alman Tapu sicil nizamnamesinin Antrag (talep) ine tekabil etmektedir. \$ 13.

(13) Tapu sicil dairesinin șekli kontrolu, tesçi talebinde bulunantr màlik clduguna değil. mâlik olarak mukayyed olup olmadigna taallik eder. Buncan. tapu siciline kaydedilmediği halde (meselà miras sebebiyle) mâlik oian kimsenin tesçilden evvel gayrımenkule tasarruf edemiyeceğ: anlașllır. Isviçre M. K. 650 II. [T. M. K. 633. II.]

(14) Vekâletname temellük edecek olana da verinebilir. Tapu sicit nizamnamesi Madde 16 II. Ostertag. 963 e ait 41 inci not.

(15) Kanunda yazıli olmamakia beraber beyanda bulunan şahsin medenî 
3-Hukukî ilìtin tersiki, İsviçre M. K. 965 III [T. M. K. 924 III] e göre bu tevsik, hukukî illetin muteberliği için aranan şeklin yerine getirildiğini ispat ile olur. Nizamnamenin 18 inci maddesini karşlaştır. Bu sebeple tapu sicil dairesi resmi şekilde yapılmış bir satıs mukavelesinin ibrazını talep etmeğe mecour olup. bu mukavelenin madcî̀ mutekerliğini kontrol etmekle mükellef değildir. (16). Buna mukabil tapu cairesi tesçilin hukukì sebebini teşkil eciecek clan aktin, munteva itibarivle yapllan bevana tetabuk edip etmecigini tetkike mecburdur. Çünkü resmî şekilden maksat taraflarm iradesini doğru ve tamam olarak aksettirmektedir. (15a) Bu iradeler tesçile esas teskil eder. Bundan dola mukavele, tesç talebinin talluk etigi ga rmenkule ait olmall (160) ve ik tarafn mükyetin intikaline miteveccih iradelerini ifade etmelldir. Mukaveleve tesçil için bï şant

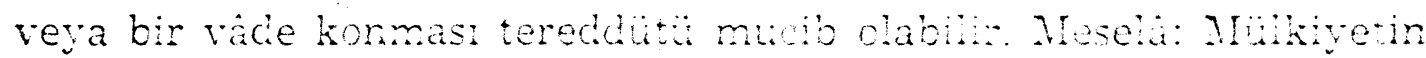

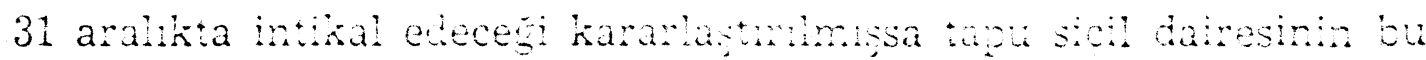
tarhten once yaphan bu tescil tatebn is at etmemest lazmdr; tes-

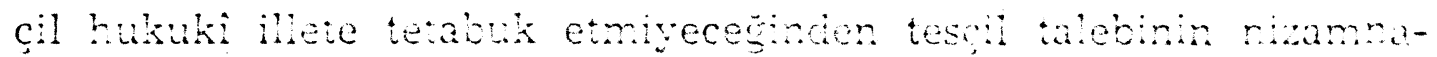
menin $2 \frac{1}{4}$ uncü mades mucibince red edines geekn (:60) Eu

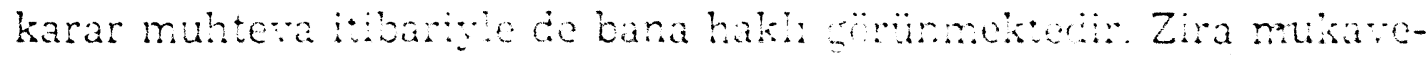

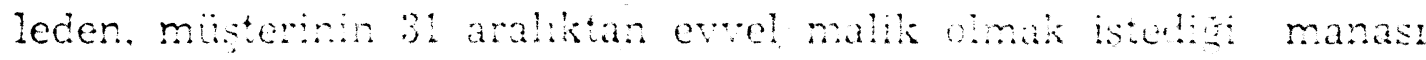

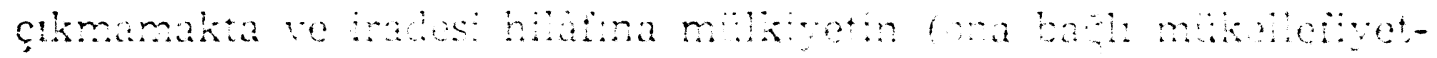

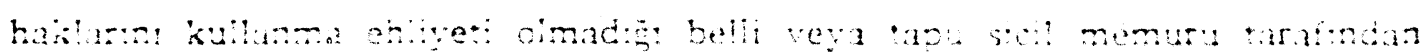

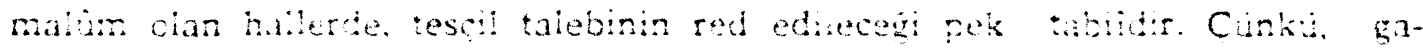

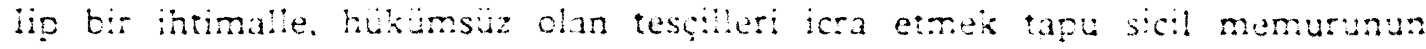
vazifeci clamaz. Ostertag ghs e ait 10 uncu nut.

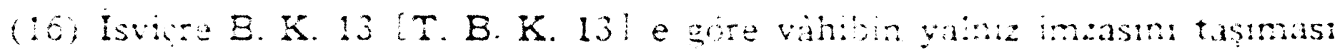
icabecten hibe vadinde de bu cartir. Bu sebepter doiay tapu sicil dairesi hibe vidinin adbul edilmis olup cimadignt tetkike mecbur degildir. Mamafit. isvige B. K. 242 III [T. B. K. 237 III] de tesçitn ancak muteber bir

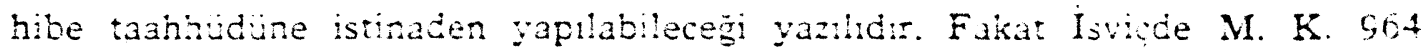
[T. M. K. 923: tascil hususurda as:l hukum oldugundan Is nunu 242 III [T. E. K. 23 III] ün sekien muteser bir hise tahüdunï kast ettiğ kabui ectlebilir.

(16a) Leemann, 657 ye ait 3 ünë not.

(i5o) Müavelede gaymenkulün tapu sicilnce gösterild ği veçhile zikredimis olmas: iàzımdı. Ostertag 963 e ait 17 . not.. așağıdaki not 74 ile karșılaștir. Fer $i k$ : taraiça kast edilen gayrmenkul mukavelede sehven yaniss gösterilmișse tesçilien evvel mukavedenin düzeitimes: lâzımdır. Leoman:ı, 657 e ait 41 inci not.

(16c) Vacieve bağlı satis aktinde iștira hakkını tapu siciline șerh verilmesiyle müșterinin hakk: temin edilmis olur. Ostertag, 959 a ait 38 inci not. 
leri ile beraber) ona zorla tahmil edilmesi tecviz edilememektedir. Tarafiar vadeden evvel tesçil hususmola mutabık kalırlarsa tapu sicil dairesi mevzuata sadık kalmak için mukavelenin noterce tadil ecilmesini istemeğe mecburcur. Mülkiyetin intikali, mukavelede bir şarta; meselâ semenin ödenmesine, bağlanmișsa (17) ve satıcı şartin tahakkukundan evvel mukavelenin tesçilini talep ederse ayni hüküm câridir. Kanaatimce tesçil, ancak roterce vapilan bir tadil ile sart mukaveleden çkarildiktan sonra caizdir. (13) Tesçil talebinde bulunan taraf. şartm verine getirildigni iddia ederse tapli dairesi bu icidianın doğn olduğuna kanaat getirmelidir. (18a) Bu așrir bir titizIik gibi görüebilir. Fakat Isviçre hukukunda, hukuki illete verilen macii ehemmiyet Gözönürde tutulursa hukuki inete terajk etmeyen tesçillerden ihtimamia kaçnmak icab ecer.

Tesçin sekle bagln baska sartan yktur. Enhasa iktsab edo-

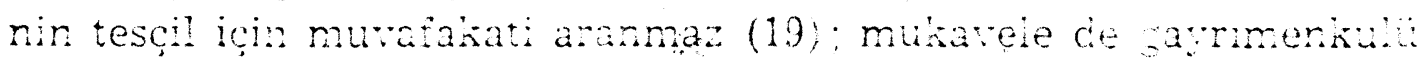
iktisab hususunda iradesin bevan etmis oimas käjer. Tescil h-

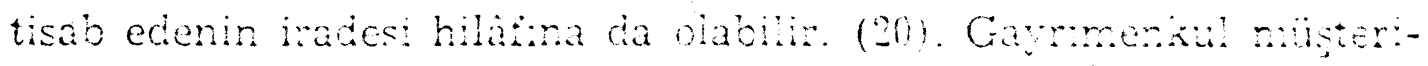

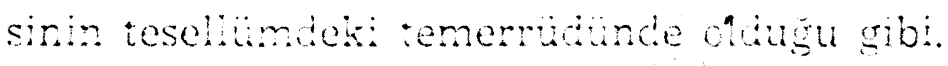

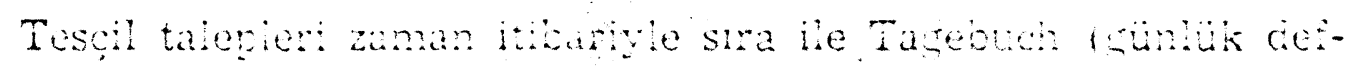

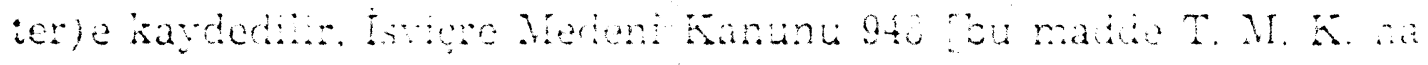

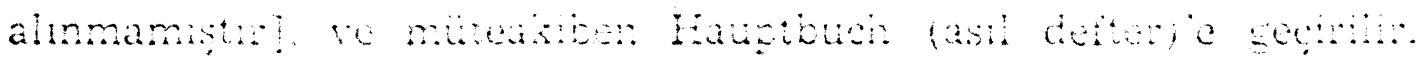
(21)

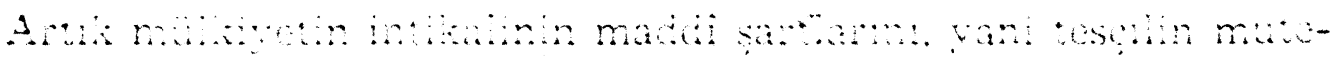

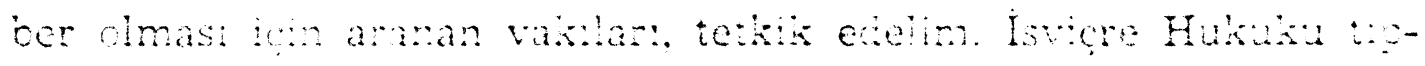

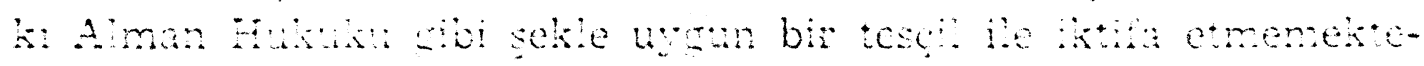

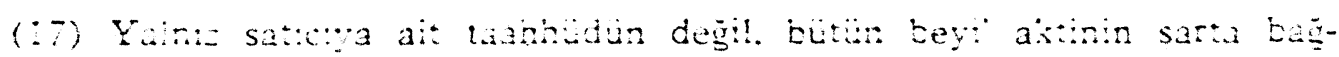

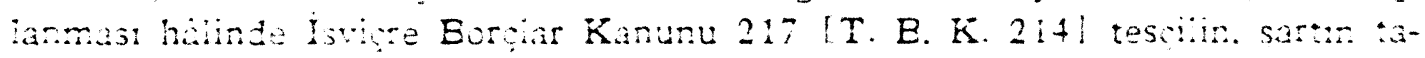
hasioundar sonea yaplabilecegini tespit eder.

(15) Așag:cia: not 34 ü karșlastar.

(18a) Eay tes t! talebinde bulunduğu vakit semenin tedyes sartnn :a edildigini iddia ederse kendisinden delil istemek icá etmez. Cünkü semenin tedye edidigin ihtive eden ikrar mevcuttur. Ostertag. 930 e at 4 No.: rotta aksi kanaattad:r.

(19) Leemann. 655 e ait 6. not.

(20) Mustani. sat:ș aktinin muteber olmadığnı iddia etse bile.

(21) Madde @ói [T. M. K. 926] "Tesçil talepleririn yapıldığ! siraya Ë̈re, demeitedir. Tesçil taiepleri (İsviçre M. K. mad. 948 e muhalif șeinide) günlük cefiera yaniss sira ìe geçirildiğinde de mi? Tapu sicil nizamnamesinin 26 rc: mad. IIr den tapu siciline kayit yapilirken günlük defterin sirasina (s:ra doğru oimasa dahî) riayet edileceği anlaşılmaktadır. 
dir. (22). Alman hukuku tesçilin yan sıra mülkiyetin naklindeki mücerret anlaşmay ararken ve mesnet teşkil eden iliete bağlı münasebetten (meselà satış aktinden) tamamen sarfinazar ederken; İsviçre hukukunda mülkiyetin intikali, hukukî illetle beraber, tesçile istinad ettirilmiştir. (22a) İsviçre Medeni Kanunu, Alman tesçil prensibi ile, borç aktinin mülkiyeti naklettirmesi hususundaki Fransiz hukuk düsüncesini șimdiøe kacar tecrübe edilmemiş bir surette mezcetmektedir.

Mülkiyetin nakli illeti muhtelif olabilir: (23) Kanuna veya vasiyetnameye dayanan miras, muayen bir malda ölüme bayll tasarruf, istimlak, cebri icra. inale, huküm, takat bihassa malkin tem-

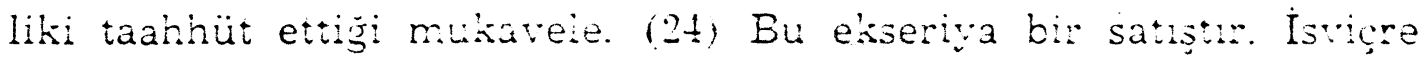
Borclar Kanununun 1T. inci [T. E. K. 1i] maddesi mücerret akteri (bir sebebi ihmo etmeyer tahhut!eri) tecriz ettignden bu gib: akitler mükiyetin nakine esas teskil edebino (25) Yant tupu dansine tesçil mesnedi olarak braz edilecel mukavelenn taraha: is-

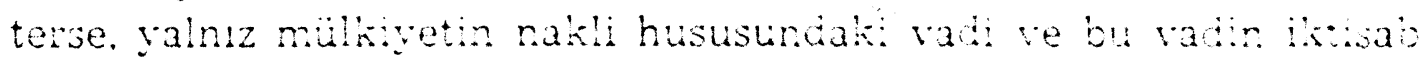

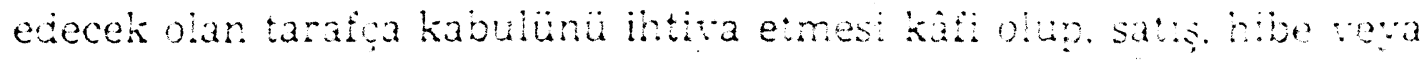

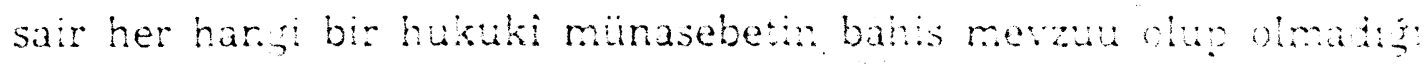
hususurda bily vermesi icap etmer.

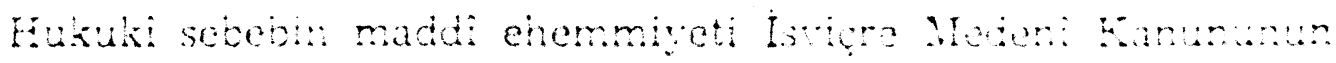

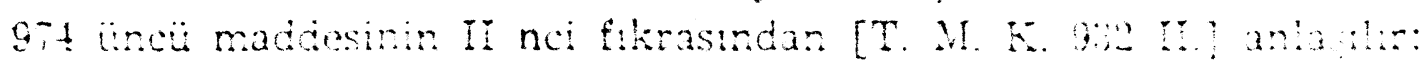

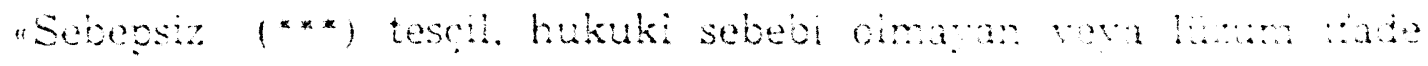

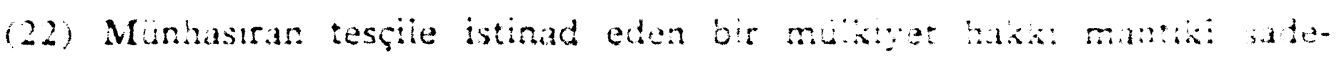

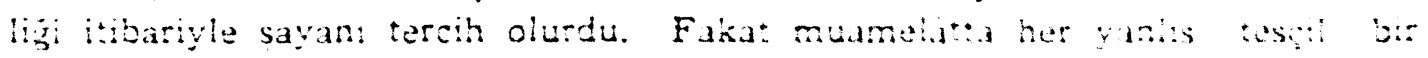
hakkn zyağna mahal vereceginden bu esas keskin bir silh durtu. 3 da aleniyet prensibinin luzumundan fazla intiam: manasng geirit Welud.

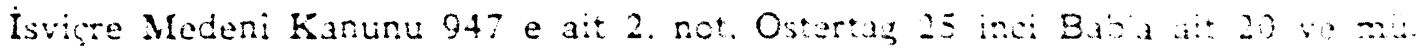

(223) Meșruiyet prensibi.

123) Nizamamenin lis inc maddesini karstast:-

(24) Mukavelenin temlik mukellefyetini hativa etmesi daj etmez. Td-

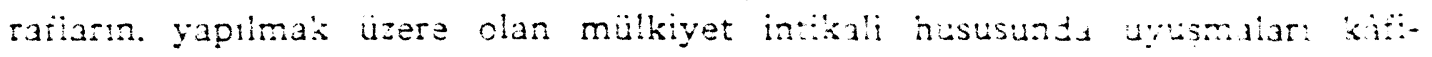
dir. Mukave.e. tapu siciline yaplan tesçil ile ifa edildkter sonra. taratlar bağanmis olur. E. Huber taksim mukavelesinin tatbik: nunasejetyle Zum Schweizerischen Sachenrecht'de S. 119 dakt not:a yyn: tikirdedir. Kanaztumce ayni surette bir hibe de yaplabilir. Vahib bir eda vadetmez yainz merhuburlehe mülkiyati intikai ettirmek hususundaki iradesin: ishar eder. Boyla bir akit teş̣il talebi için șeklen yeteceği gibi maddi bak:mcian da tescilin ecası olabilir. Fakat tesçil talebinin yapliması için bir taahinut deḡildi--

(25) Huber. Zikredilen eser.

(***) Mütercim notu: İsviçre M. K. daki "Ungerechtfertigt, sözü "sebepsiz" șeklinde tercüme edimiş̧tir. v. Tuhr Aligemeiner Te:! des Schwei- 
etmeyen hukuki bir muamele mucibince yapılan tesçildir." Isviçre B. K. 62 [T. B. K. 6i] ve Pandekt hukukunda sebepsiz iktisab için teknik terim olan Lngerechtfertigt (Sebepsiz) kelimesi, burada mülkiyeti nakleden fakat sebebinin bulunmamasindan dolay eski haline irca imkânını veren bir tesçilin mavzuubahis clauğu düsünncesire sev edebilir. Ancak Isviçre Medeni Kanunu 974. 97j (26) [T. M. K. Q32, 933] deki sebepsiz kelimesinin enemmiveti daha büvuktür: tesçi hükümsüzdür ve bundar dolay sahih değidir. Temlik eden mâlik kairr (27) ve Isviçre Mederi Kanunu 97j [T. M. K. 933] e göre gerek iktisab edene gerek hukuki sebebin noksanhon bilen vera bilmesi icab eden her üçüncü șahsa karșı tesçilin (27a) tashinini dâa edebilir. Isviçre M. K. 974 I ve III [T. M. K. 932 I. ve III]. (28). Mibloivet iktisabı hukuki illetin dogru olmasina baghl tüulmakla mesretsiz mäkiyet nakilerini ölenmistir. Halbuk Alman Hukukunda bu gibi haller vukua gelebimekte re borçar hukukuna dayanan vastalaria (scbepsiz mal ikisab! mutalebeleriyle) izale edimektedir. (28a) Is-

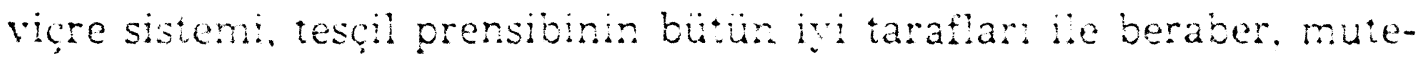
ber olmayar temlik mamejelernan neticelerne kary malka Aman

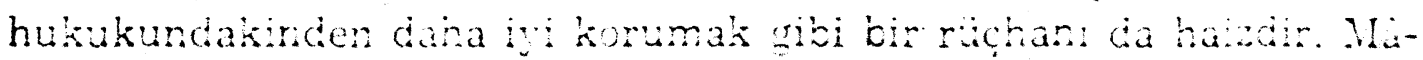

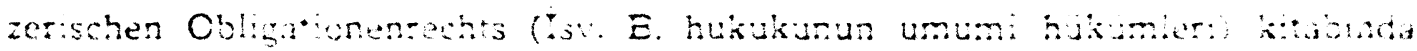

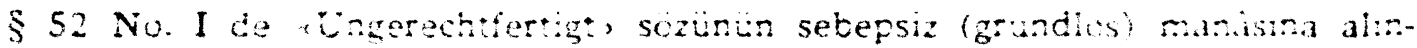

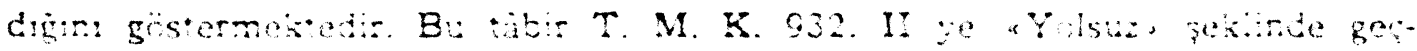
mistir.

(26) Ayn sexide Istace Medeni Kanunu 6n! IT. M. K. 038 :

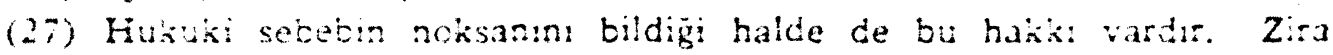

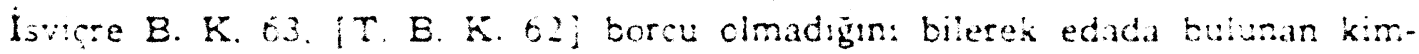
seye sebepsiz ma iktsab muialebesint tanmamis ise de muktyet hakknn cermeynni mentmemistir.

(27a) Eu dava Aiman Mederi Kanunu $\$ 894$ un tashih mutalebesine tevafuk eder. Iovice M. K. 97/ [T. M. K. 935] Berichtiging (tashih tabiryle maçi hukuk durumura temas etmeyen tesçil hatalarnn duzeitilmesin: kast etroktedir.

(28) Tapu sichne màk im!s gibi tesçi edilenin, doğru clmayarak lehine yapumıș bir tescili bertaraf etmek için elinde bir vasıta olmalıdr. Bu vasita, yanlss tesçili yaptirm:s oian selefi aleyhine açabileceği tesçilin tashihi davasidir. Maamafïh tashih dâvası İsviçre M. K. 975 inci [T. M. K. 933] maddesinde yainz tesçil ile ayni hakları haleldar edilmis olana tanınmıștır. Çünki kanun Alman Medeni Kanunu $\S 894$ de olduğu gibi yalnz mutat vaziyeti. yani tashihin bir ziyağin önlenmesi için arzu edileceğini düșinmüstür. Kanaatimizce bilhassa İsviçre Medenî Kanununda genişletici bir tefsir yerindedir. Cünkü tesçilin temellük edenin iradesi inzimam etmeden yapilması mümkündür. Yukardaki 19 uncu not ile karșılaștır.

(23a) Strahe!, Leipziger Zeitschrift. 1909. S. 613 karșılaștır. 
lik mülkiyet hakkm kaybetmez. (29). Màlik mülkiyet hakkm hasminın iflâsında da kaybetmiveceği gibi (30) hasminın hukukî halefine karşı da kaybetmez. Meģerki bu hukukî halef hüsnünivet sahibi ola. İktisab bahsinde İsviçre M. K. 975 [T. M. K. 933] den bir güçlük doğabilir. İktisab eden hüsnüniyet sahibi ise vazivetinden emindir. Ancak hüsnüniyetin. temlik edenin gayrımenkulü iktisab ederker. dayandığı borç aktine de şümulü vardır. X, A dan bir ev satın aimak istediğinde. A ile onun hukukì selefi B arasinda - Satıs aktinin muteber olup olmadığ hususunda- bir nizanın mevcudivetinden haberdar olursa. vaziyetinden emin olmas: için bu satıs aktinin muteberliği hakkında bir fikir edirmesi làzım gelir. Bu lïzum halin icabına göre bu derece ihtimam kendisinden beklenebileceši hususlarda caridir. (Isviçe Meceni Kanunu Macle 3) [T. M. K. 3]. Alman hukukuna göre $\mathrm{X}$. A re $\mathrm{B}$ arasmdaki yaknen vaki olmact be al akt ile alakadar olmaga mecbur değildir. A ve $\mathrm{E}$ arasrdas certude bir hata mevcut olduğunu bilmedigh müddetce hasnun retli saylu.

Kanun madde 947 II [T. M. K. 932 II] de sebersin teschn iki hal:ni zikreder:

1. Fukuk: bir sebep oimadan, yani o ana kadar mak olat A

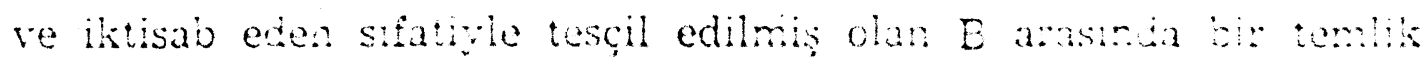

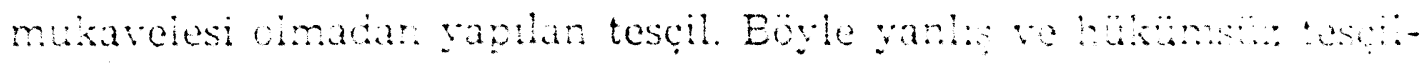

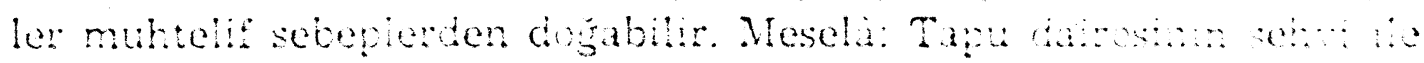

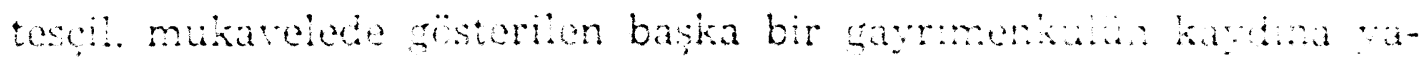

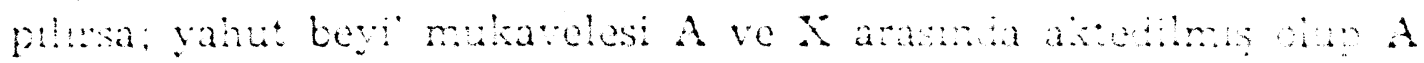

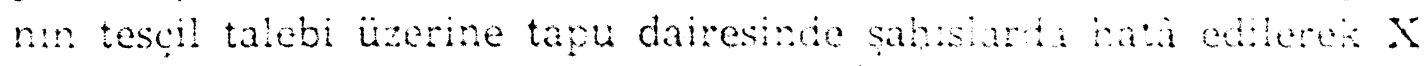
yerine ismen müsabini olan B tesci! edilmis chns Yahe. A resme

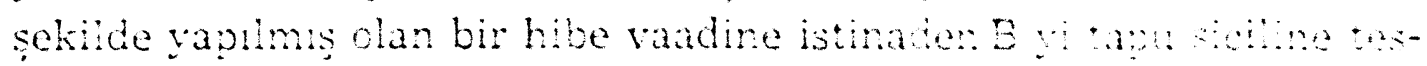

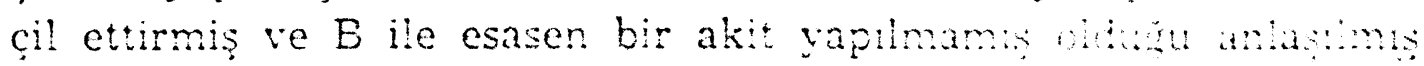

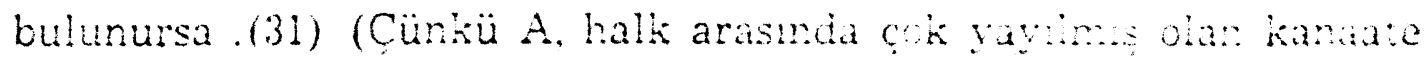

(29) Tapu siciondeki kayda göre malk oldugu artik andastmamata beraber. Isvicre Medeni Kanuni 971 [T. M. K. 929: maddesini dar tersi e:mek làzmdir. Bu madde yalniz, teessüsier içn yaplmas: luzumlu teşị yaplmamasi sebebiyle vicut bulamamis olan haktara taallik eder. Ostertag. 971 e ait 16 not.

(30) Ostertag 975 e ait not 36. Alman hukukunda vaziyet baskadir. Orada mesnetsiz mülkiyet intikalinin eski hale ircağ borçlar hukukuna dayanan bir sebepsiz iktisab mütalebesi ile yapilu. Alman sisteminin çok kere hakkaniyete aykirı görünen bu neticesi için benim Allgem. Teil $\$ 73$ not 52 ye ve aynı zamanda aşağıca not 82 ye bak.

(31) İsviçre Medenî Kanunu 965 III [T. M. K. 924 III] e göre tapu dairesinin tetkiki hukuki sebebin şekline inhisar etmektedir. Yukardaki Not 15 ile karṣllaștir. 
istinaden hibenin kabule bağlı olmadığını zannetmektedir.). Ve yahut $\mathrm{A}, \mathrm{B}$ ile bir satış akti yapmiş ve mümessili $\mathrm{X}$ i tapuya, tesçil için, müracat ile tavzif etmiş olur ve müteakiben akit İsviçre Borçlar Kanunu 115 [Bu maddede T. B. K. alınmamistır] e istinaden $A$ ve $B$ tarafından şekle bağlı olmavan bir sözleșme ile kaldırılmıs (31a) ve fakat bundan zamanında haberdar edilmeven $X$ aktin tesçili için tapuya müracaatta bulunmus olursa. Bütün bu hallerde $B$ namina yaprlan tesçil sebepsizdir ve İsviçre M. K. 975 [T. M. K. 9.33] e istinaden tadil yolu ile bertaraf edilebilir. Bununla beraber noksan olan hukukì sebep tanamlanabilir. (32) Tescilden sonra A ve B seklen muteber bir temlik mukavelesi aktederlerse tesçilin tekrarianmasina ihtiyaç olmadan, mukavelenin akti ile, mülkiyet $B$ ye intikal eder. (33) Beyi akti veya bàinin tahhüdü șarta veya bir vâdete bağlanmis ise. tesçion -bir müddet için hukuki sebebi bulunmyacağncian- kanaatimce yapllmamas: làzımdir. (34) Bu halcie tesçil sebepsizdir ve temlik eden henüz màlik slfatını muhafaza etmektedir. (35) Bununla beraber şartin tahakkuk edemiyecesinin ankaji-

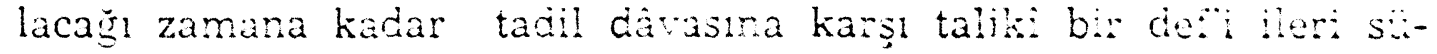
rülebilir. (36)

2. Eundar baska Is vere M. K. 97t II [T. M. K 932 II] ye luzum tfade etmegn bir hukuki muameleye istinaden gathe osril de sebepsizin. Muamelenin luzum ifade etmemest mu

(31a) Leemunn. 557 e ait 19 uncu not.

(32) Son misaldeki sat:ș mukavelesi șekle bağh cimayan bir aniama tie mutecer hale getiritemez. Bilikis. taraflarin Isviçre M. K. 65: [T. M. K. 63t] nin kabul ettigi șekle rayet ederek yeni bir satts mukavelest aktatueder: hazimdir.

(33) Ostertag, 971 e ait + üncü not. Muhatabn muvatikati oimaden ypllan hibede. B. nin tesçile muttali olduktan sonra muvaffak beyan: ile s:beyi tekemmül ettirebilmesi ve malik stfatin ihraz edebimesi suphelib:- Eurada A tarafindan yapilan tesçilin $B$ ye kaş̧ vâti bir icap mahive:inde ciop olmadiğna ve icabin temadi edip etmedigine bak:irr.

(34) Yukardaki not 18 i karșlaștir.

(35) Bâyinin, Ísviçre Borçlar Kanunu 82 [T. B. K. 81] ye göre anca': semenin tediyesi mukabilinde ifa ile mükellef oldugu düşünulerek taahhüji șarta bağlı telàkki edilemez. Mukavelenin ifa edilmemesi def'i (exc. non adimpleti contractus) Isviçre Hukukuna göre de hakikî bir defidir, Becker, Borẹlar kanunu 82 ye ait 1 ve 7 nci notlar. Bundan dolayı semenin tediyesinden evvel müşterinin tapuya tesçil edilmesi sebepsiz bir muamele teșikil etmez ve bâyi sicilin tashihi talebinde bulunamaz. Görünüșe göre Wieland 963 e ait 2 b notunda baska fikirdedir.

(36) Benim 4llg. Teil III S. 257 i karșilaștır. 
beplere dayanabilir; bunlardan en mühimlerini zikrediyorum:

a) Şekil noksanı. İsviçre M. K. 657 [T. M. K. 634] ye göre akit için aranan resmî şekil kanton hukukuna tâbicirir. (37). Şekle bağlı hangi anasırın hukuki muamele için muteberlik şartı teşkil ettiği, ve resmî muameleyi yapan memurun salahiyetil olup olmamasina göre muamelenin muteber olup olmadığ meseleleri de kanton hukukuna göre hailedilir. Kanton Hukukuna göre beyi akti, bir sekil noksanı sebebivle (38), tarafları bağlamıorsa yapılan tesçil, -șekil noktasindar İsviçre Medenî Kanunu 965 III [T. M. K. 92t] ün emrettiği kortrol yapilmis olsa bile- sebepsizair. Atman Medenî Kanunu § 313 de oldugu gibi șekil yanlışighnn tesçil ile sslahı Isviçre hukukunda derpiș edilmemistir. (39) Zaten Isviçre Medeni Kanununun sistemine de uymazd. Zira tesch. Temellü edenin muvafakati clmadan. temlik edenin bir tarah muracati ile yapilir. Iktisab eden temlik ecienin satis aktincek! şck: noksanm ieri

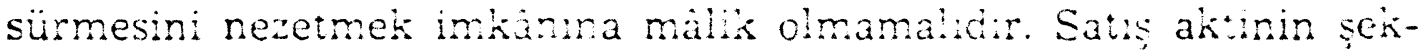
le lygun clmaması sebebivie sebepsiz clan tesci Istiçe Medeni Kanunu 975 [T. M. K. 930) e qöre temlik ecunin açacas dava lie

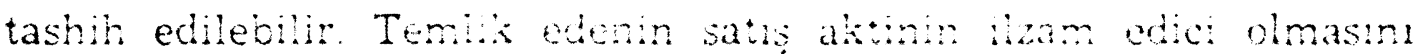

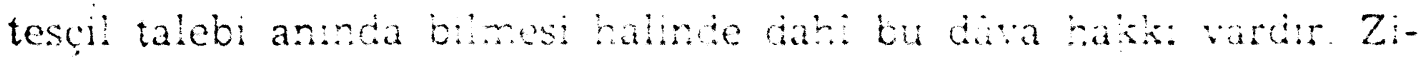

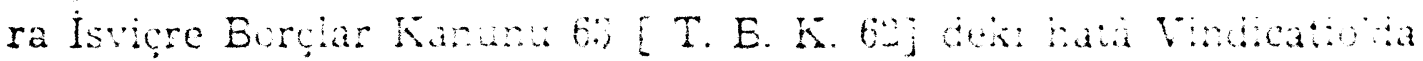

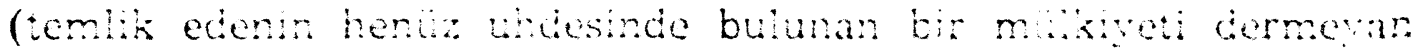

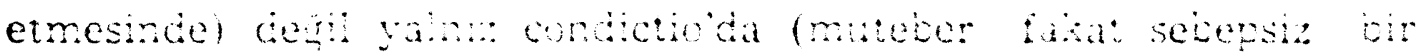

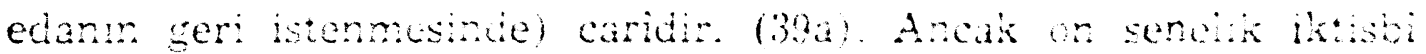

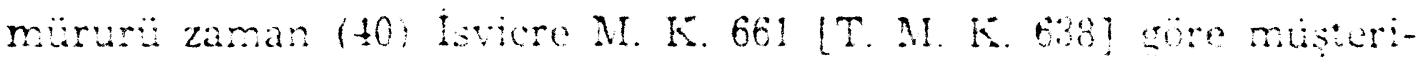

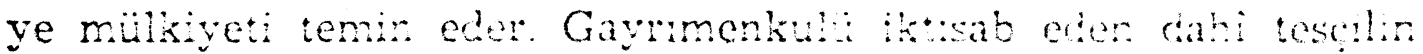
yapumis clmasina ragmen. satı̣ aktince bu sek! nukan: bulundu-

(3i) Wieland Isvicre Medeni Kanunu 657 icin 3 ve 6 no nct: Leemann, 657 için 30 ve müteakip notlar.

(38) Meselà: resmî senedi tanzim eden memurun salàhyetsiz olmas: veya semenin yanlus bildirimesi, neticesi clarak.

(39) Leemann. Isviçre Medeni Kanunu 657 ye ait 52 inci not.

(39a) Saticı, şekil noksanin ve satıșin butlanin bildiğ halde de tedye etmis olduğu semeni geri istiyebilir. Kendisinin bu vaziyette bir borcun edası maksadiyle değil, karșı tarafın satıșı batıl ad etmiyecuğine intizaren tediyede bulunduğu kabul edilebilir. Reichel, Arch. f. zivil. Praxis. 104. 27, Becker, Eorçlar Kanunu 11 e ait 5. not, Leemann, 657 e ait 55 inci not.

(40) Satış aktindexi şekil noksanının bilinmesi kanaatimce iktisabi müruru zaman için làzım olan hüsnüniyeti bertaraf etmeğe kâfi değildir. Zira iktisab eden, hukukî vazyeti bilmemek mazeretiyle, mülkìyet hakkindan emin olabilir. 
ğunu ileri sürebilir. Bunurila gayrımenkulü iktisab eden için semenin istirdadı mütalebesi doğar. (40a) İsviçre B. K. 67 e [T. B. K. 66] göre bu mütalebe hakki, hakkin mevcudiyetine ittilà kesbedildigi tarihten itibarer bir sere, ve en geç mütalebe hakkmn doğumundar iticaren on sene geçmekle müruru zamana uğrar. Saiıs akti, tesçil ve tediye ile taraflarca ifa edilmisse, mukavelenin, bir șkil hatası secebiyle ortadan kaldmimasina birçck hallerde hukuzi hissimiz razi olmaz. Çünü şeklin er mühim gayesi tarafları düşürülmeden ve acele edilevel verien kararlarm neticelerinder korumaktadır. Fakat mukavele tarafiarca görül razası ile ifa edimisse sözleşmenin muhtevà itibariyle klisursliz oldugu, ve görünmeyen veya nazan itibara almmayan bir sekil yarhsindan dolay akti bozmak teşebbüsünün, bu arada meydana gelen fiyat farkndan istiface et-

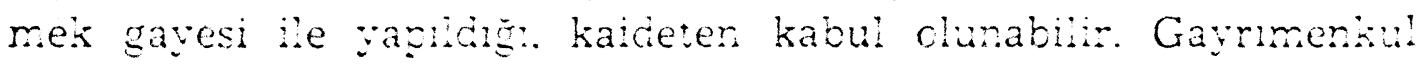
Ḧatar yuksedig zaman mukavelece, tapu memunum gëzin-

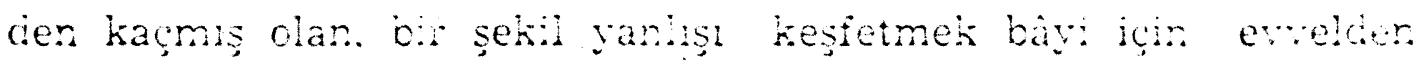
ahmin etmedigt re hak etmengi bir saadet ohur. Boyle tesade-

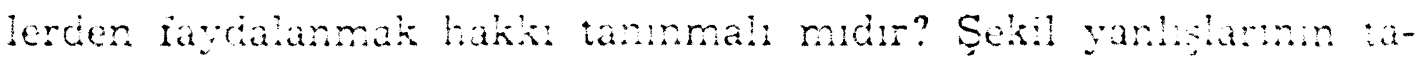

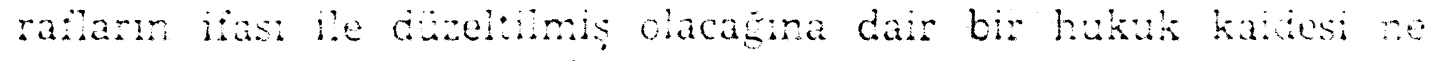
Alman Fukukunda re de Iswere Medeni Kanunurda buhnmima-

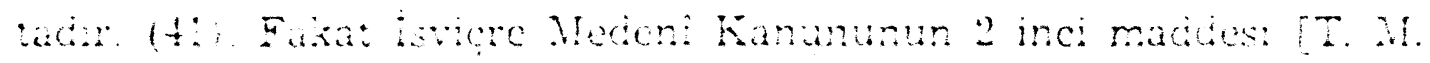

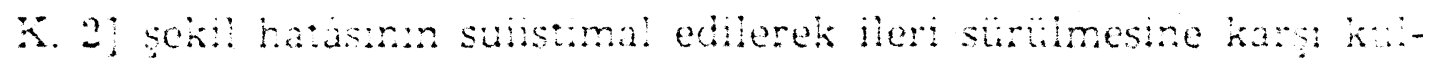

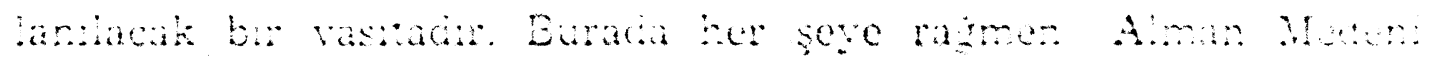

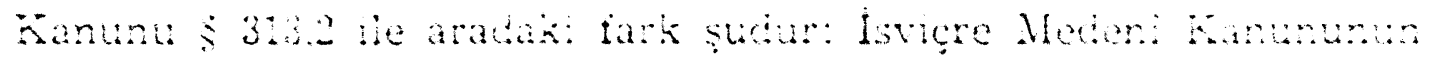

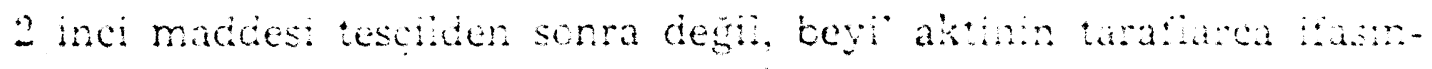

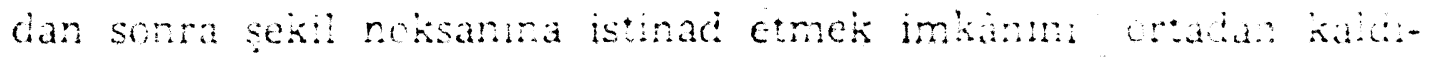
ris.

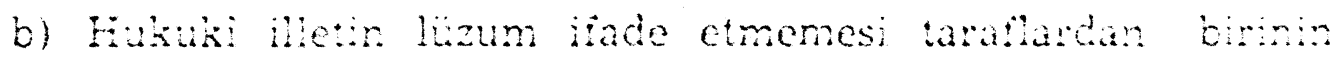
- iapu daresince anlashamayan- (4) medeni hahamn kuhama salahyetinden mahmu cimasma dayanabilr. Tarmarkan binn

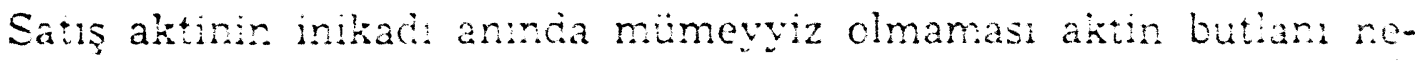
ticesini dogurur. Is içe M. K. 10 [T. M. K. 15] Kanun mümesin. veya temyiz kudretin yenicien iktisab ettikten sonra bay tescil talebinde bulunsa bile beyi akti gene bâtì kalir ve bundan cola tesçil sebepsiz olur. Tesçil ancak, temyiz kudretirin iktisabndan

(40a) Isviçre Borçlar Kanunu 63 e göre yalnız satıs aktinin muteber niduğ hususunda hata edilmisse.

(41) Reichel. yukarda zikredilen eser S. 33 de bc̈y!e bir kanuni hükmü haklı olarak müdafaa etmektedir.

(42) Yukardaki not 15 i karşılaștır. 
sonra madde $6 \overline{5} 7$ deki şekilde aktedilen yeni bir satış akti ile doğru bir hale gelir. (43). Taraflardan biri mümeyyiz, fakat reşit değilse veya vesâyet altındá ise, İsviçre M. K. 19 [T. M. K. 16], ve kanunî mümessilinin rizası olmadan hareket ediyorsa beyi' akti lüzum ifade etmez, İsviçre Medenî Kanunu 410 [T. M. K. 39t]. Ancak bu akit kanunî mümessilin veya medenî hakları tam kullanma salăhiyetini elde eden âkidin icazeti ile muteber olabilir. İcazetin sarih olması icabetmez; aktin tesçili için vapllan talepte mündemiç olabilir. Müsteri medenî haklarını mahdut surette kullanmağa salàniyettar ise iradesi olmadan yapılan tesçil ile akit muteber hale gelmiveceğinden tesçil sebepsizdir. Fakat bayi mukaveleye bağl oiup ancak 410 uncu maddenin II inci fikrasma göre minasip bir mehit tayini ile kendisini akti baghlliktan kurtarabilir. Borç aktine baght kaldığ müddeiçe İviçre Medeni Kanunu 975 [T. M. F. 90] des: Tadil davası kendisine tarmmamstutr.

$$
\text { (Encu vas) }
$$

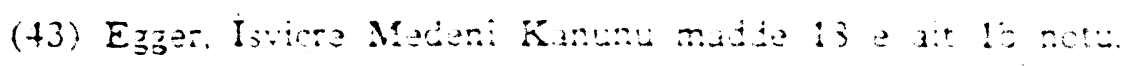

